\title{
EFFECTS OF STRUCTURAL CHANGES IN INTERMEDIATE USE ON EMPLOYMENT USING THE INPUT-OUTPUT ANALYSIS AND THE INDEX THEORY
}

\author{
KAREL ŠAFR $^{\mathrm{a}, *}$, KRISTÝNA VLTAVSKÁ ${ }^{\mathrm{a}}, \mathrm{JAKUB} \mathrm{FISCHER}^{\mathrm{a}}$ \\ karelsafr@gmail.com, kristyna.vltavska@vse.cz,jakub.fischer@vse.cz
}

\begin{abstract}
a University of Economics in Prague, Faculty of Informatics and Statistics, Department of Economic Statistics, W. Churchill Sq. 4, Prague, Czech Republic
\end{abstract}

\begin{abstract}
The aim of this paper is to investigate the effect of structural changes in intermediate use on employment in the Czech economy. We combine the input-output analysis with the index theory. For the analysis, we use input-output and employment data for the period between the years 2005 and 2015. We focus on the strength of the relationship between final use and employment through intermediate use and analyze how structural changes in intermediate use affect it. The results show that the structure of employment did not rapidly change and did not affect this relationship. However, changes in the structure of intermediate use have a significant effect on the relationship between consumption of national goods and Czech employment. We can state that Czech industries changed their intermediate consumption from goods that are highly dependent on employment to goods that are less dependent. This effect can be caused by the increasing price of manpower over time.
\end{abstract}

\section{Key words}

input-output analysis, index analysis, index theory, employment, structural analysis, structural changes

\section{JEL classification}

C67, D57, E24, L16

\section{Introduction}

Nowadays, the Czech Republic is facing structural changes in the economy, emerging from the processes of digitization and automation. These processes and its consequences are usually called as the process of Industry 4.0 (Lasi et al., 2014) and have a significant impact not just on the production side of economies, but also on the labour market. There are supposed strong changes in the structure of employment by industries and changes in foreign trade.

Concurrently, the digitization and automation cause some structural changes in economies. Labour force becomes more expensive compared to physical capital. When the companies optimize their production processes and total costs of production, they can shift their intermediary consumption from the goods and services with the higher workload to the goods and services which are less demanding on the labor force. This can cause some structural changes in the economy, measured by the change in multipliers.

The aim of this paper is to investigate the effect of structural changes in the Czech economy. We analyze these effects by Input-Output analysis combined with thinking of index theory. We focus on the source of changes in employment multipliers between the years 2005 and 2015 . As we do not have Input-Output tables (I-O Tables) at the stable price we develop a new methodology combined with price change in Supply and Use tables (SUT).

There are several sources of change of Leontief multipliers of employment. From a mathematical point of view, it comes from the changes of input-output coefficients. 


\section{The source of employment multipliers changes}

The analysis of the stability of Input-Output tables has the same long history (e.g. Carter 1970; Guo and Planting, 2000) as the I-O Tables exists. Leontief used it for the study of the structural changes of the Input-Output economy over the period 1919-1929 and 1919-1939 (Leontief, 1951; Leontief, 1941). Generally, the key idea of all ways how to compare the structural changes is based on modelling the impact of the change of intermediate matrix in the Input-Output system when all other data remains the same. This allows us to measure how significant impact has some change in total production/gross value added/employment and other indicators (Miller and Blair, 2009).

As Miller and Blair (2009) state there are many economic factors why coefficients of inputoutput models vary over time:

I. Technological change itself (the way how goods are produced).

II. Rapid growth of demand can produce economies of scale.

III. Newly invented products.

IV. Price change and the substitution effect.

V. In aggregated tables we will face the problem of changing the weight of the inner product.

VI. Changes from domestically produced goods to imported products.

From the mathematical point of view, the Input-Output models are based on the relationship of two ways how the total output can be calculated. Firstly, total output from the view of use is a sum of intermediate use (the sum of supplied goods), the final use of goods and export. From the production point of view, it is the sum of demanded goods into production (intermediate use), gross value added and import. In the Input-Output analysis, we assume that the production of one sector is in fix relationship to employment. Thus, the effect of change of employment can be caused from the production point of view by:

I. level and structure of employment,

II. price changes between years in intermediate use and gross value added,

III. changes in the structure and value of intermediate use,

IV. changes in import.

Miller and Blair (2009) summaries the most used way of how structural changes are evaluated. These methods are The Comparisons of Direct-Input Coefficients, Comparisons of Leontief Inverse Matrices and Measures matrices. The Comparisons of Direct-Input Coefficients are based on the difference of x-coordinates (the size of technical coefficient in year $t$ ) and y-coordinates (the size of technical coefficient in year $t-k$ ). Leontief Inverse Matrices comparison is based on comparison the value of Leontief multiplier or on the comparison of the forecast of production based on final use.

Dewhurst (1993) provided alternative method of the decomposition of the Input-Output tables - based on partial decomposition of each effect by splitting the effects between base and current period. Sonis et al. (1996) extended Dewhurst method for more thorough analysis in years 1948-77 (three tables). They decompose the change into three components for each sector. Das (2013) used the analysis changes in Dynamic Input-Output model for measuring the effect of structural change on the prediction from this model over several periods.

\section{Data}

We use data provided by the Czech Statistical Office, namely from the Database of National Accounts ${ }^{1}$. We use Symmetric Input-Output tables in current prices for years 2005, 2010 and 2015. Supply and Use tables in current and previous years prices for years

\footnotetext{
${ }^{1}$ Available at http://apl.czso.cz/pll/rocenka/rocenka.indexnu (accessed 2019-02-01).
} 
2005 - 2015. And the total employment (hours worked) for the years 2005, 2010 and 2015. All calculations are prepared using the Classification of Economic Activities (CZ-NACE). The areas of economic activity in line with CZ-NACE are listed in the Appendix.

\section{Methodology}

From the use side, the total output of $i$-th industry $\left(x_{i}\right)$ can be described as the sum of intermediate use ( $x_{i j}$-flow of goods from $i$-th industry to $j$-th industry to intermediate use), final use ( $f_{i}$ - the final use of goods $i$-th industry) in the form of equation

$$
\sum_{j=1}^{n} x_{i j}+f_{i}=x_{i}
$$

From the production side of view, the total output can be calculated as the sum of demanded intermediate use and gross value added by each industry $\left(z_{j}\right)$ using equation

$$
\sum_{i=1}^{n} x_{i j}+z_{j}=x_{j} .
$$

We can establish technical coefficient matrix (A) with elements $a_{i j}$ as a ratio

$$
\frac{x_{i j}}{x_{j}}=a_{i j}
$$

Technical coefficients can be described as the fix proportion of intermediate use to total output. The production function can then be written as

$$
\boldsymbol{x}=(\boldsymbol{I}-\boldsymbol{A})^{-1} \boldsymbol{f},
$$

where $\mathbf{x}$ is vector of the total output $\left(x_{i j}\right)$ and the matrix $\mathbf{I}$ is identity matrix, the $\mathbf{f}$ denotes to vector of final use $\left(f_{j}\right)$. The key part of this equation is the inverse matrix: $(\mathbf{I}-\mathbf{A})^{-1}$ which is named as the Leontief inverse and is known as a matrix $\mathbf{L}$ (with elements $l_{i j}$ ). The column sums of this matrix refer to the Leontief multipliers defined as

$$
m_{j}=\sum_{i=1}^{n} l_{i j}
$$

The interpretation of this multipliers is how much will be changed the total output in the economy by the change of final use of goods from $j$-th industry. These multipliers can be recalculated into employment multipliers which refer to the change of total employment in the economy caused by the change of final use using formula

$$
m_{j}^{e}=\sum_{i=1}^{n} \frac{v_{i}}{x_{i}} l_{i j}
$$

where the $v_{i}$ denotes to the employment in $j$-th industry (in our case for total worked hours).

\section{Comparison}

We decided to evaluate the differences which come from the changes in the economy by Leontief inverse matrix. We calculate these measures for Employment multipliers $m_{j}^{e}[\mathbf{A}, \mathbf{v}]$ where $\mathbf{v}$ is a vector of employment. We evaluate the effect of change of employment as Fischer index defined by

$$
\text { Fischer index of employment in } j \text {-th industry }=\sqrt{\frac{m_{j}^{e}[1,1]}{m_{j}^{e}[1,0]} \frac{m_{j}^{e}[0,1]}{m_{j}^{e}[0,0]}},
$$

where 1 denotes to the current period and 0 to the base period. On the other hand, we can evaluate the overall effect of structural changes in the economy as 
Fischer index of structural changes in $j$-th industry $=\sqrt{\frac{m_{j}^{e}[1,1]}{m_{j}^{e}[0,1]} \frac{m_{j}^{e}[1,0]}{m_{j}^{e}[0,0]}}$.

The problem of these indices arises from the fact that the matrix $\mathbf{A}$ is in current prices and it contains the changes of ratio between intermediate use and gross value added. Thus, we construct the technical coefficient matrix in constant prices that refers to several situations as $\mathbf{A}$ [year, price, ratio of intermediate use to total output].

The procedure of the calculation of the technical coefficients matrix in different years prices is based on the Supply and Use tables from which we calculate price change for domestic goods each year $-d_{i}$. Then we can re-estimate the matrix $\mathbf{A}$ in prices of year $t$ as

$$
a_{i j}[0,1,0]=\frac{d_{i} x_{i j}[0,0]}{\sum_{i=1}^{n} d_{i} x_{i j}[0,0]}\left(\sum_{i=1}^{n} x_{i j}[0,0]\right) \frac{1}{x_{j}[0,0]},
$$

where $x_{j}[$ year, price] is intermediate use for specific year and specific price of the $j$-th good. $a_{i j}[0,1,0]$ refers to the technical coefficient for base period in current prices with respect to the proportion of intermediate use to total output for base period.

$$
a_{i j}[0,1,1]=\frac{d_{i} x_{i j}[0,0]}{\sum_{i=1}^{n} d_{i} x_{i j}[0,0]}\left(\sum_{i=1}^{n} x_{i j}[1,0]\right) \frac{1}{x_{j}[1,0]} .
$$

Similarly, coefficient $a_{i j}[0,1,1]$ introduced by the technical coefficient for the base period in prices of the current period which is benchmarked into the proportion of intermediate use to total output for the current period. Following equations evaluate the effect of changes ceteris paribus. Then the effect of structural change on the economy can be estimated by Fischer-like index introduced by

$$
\begin{gathered}
{\left[\frac{m_{j}^{e}[\mathbf{A}[1,0,0], 0]}{m_{j}^{e}[\mathbf{A}[0,0,0], 0]} \frac{m_{j}^{e}[\mathbf{A}[1,1,0], 0]}{m_{j}^{e}[\mathbf{A}[0,1,0], 0]} \frac{m_{j}^{e}[\mathbf{A}[1,0,1], 0]}{m_{j}^{e}[\mathbf{A}[0,0,1], 0]} \frac{m_{j}^{e}[\mathbf{A}[1,0,0], 1]}{m_{j}^{e}[\mathbf{A}[0,0,0], 1]}\right.} \\
\left.\frac{m_{j}^{e}[\mathbf{A}[1,1,1], 0]}{m_{j}^{e}[\mathbf{A}[0,1,1], 0]} \frac{m_{j}^{e}[\mathbf{A}[1,0,1], 1]}{m_{j}^{e}[\mathbf{A}[0,0,1], 1]} \frac{m_{j}^{e}[\mathbf{A}[1,1,0], 1]}{m_{j}^{e}[\mathbf{A}[0,1,0], 1]} \frac{m_{j}^{e}[\mathbf{A}[1,1,1], 1]}{m_{j}^{e}[\mathbf{A}[0,1,1], 1]}\right]^{1 / 8} .
\end{gathered}
$$

When the value of this index (11) is lower than 1 it means that the structural changes in production functions negatively affect employment multiplier(s). For values higher than 1 the index refers to the fact that the structural changes positively affect the value of employment multiplier(s). Then the effect of the change in the prices of goods on employment can be calculated as:

$$
\begin{gathered}
{\left[\frac{m_{j}^{e}[A[0,1,0], 0]}{m_{j}^{e}[A[0,0,0], 0]} \frac{m_{j}^{e}[A[1,1,0], 0]}{m_{j}^{e}[A[1,0,0], 0]} \frac{m_{j}^{e}[A[0,1,1], 0]}{m_{j}^{e}[A[0,0,1], 0]} \frac{m_{j}^{e}[A[0,1,0], 1]}{m_{j}^{e}[A[0,0,0], 1]}\right.} \\
\left.\frac{m_{j}^{e}[A[1,1,1], 0]}{m_{j}^{e}[A[1,0,1], 0]} \frac{m_{j}^{e}[A[1,1,0], 1]}{m_{j}^{e}[A[1,0,0], 1]} \frac{m_{j}^{e}[A[0,1,1], 1]}{m_{j}^{e}[A[0,0,1], 1]} \frac{m_{j}^{e}[A[1,1,1], 1]}{m_{j}^{e}[A[1,0,1], 1]}\right]^{1 / 8} .
\end{gathered}
$$

This index (12) evaluates the effect of prices of each good on the multiplier. When the number is lower than 1 it means that the prices negatively affect the employment multipliers and vice versa. The effect of proportion (gross value added and import for domestic production) can be estimated as follows

$$
\begin{gathered}
{\left[\frac{m_{j}^{e}[A[0,0,1], 0]}{m_{j}^{e}[A[0,0,0], 0]} \frac{m_{j}^{e}[\mathbf{A}[1,0,1], 0]}{m_{j}^{e}[\mathbf{A}[1,0,0], 0]} \frac{m_{j}^{e}[\mathbf{A}[0,1,1], 0]}{m_{j}^{e}[\mathbf{A}[0,1,0], 0]} \frac{m_{j}^{e}[\mathbf{A}[0,0,1], 1]}{m_{j}^{e}[\mathbf{A}[0,0,0], 1]}\right.} \\
\left.\frac{m_{j}^{e}[\mathbf{A}[1,1,1], 0]}{m_{j}^{e}[\mathbf{A}[1,1,0], 0]} \frac{m_{j}^{e}[\mathbf{A}[1,0,1], 1]}{m_{j}^{e}[\mathbf{A}[1,0,0], 1]} \frac{m_{j}^{e}[\mathbf{A}[0,1,1], 1]}{m_{j}^{e}[\mathbf{A}[0,1,0], 1]} \frac{m_{j}^{e}[\mathbf{A}[1,1,1], 1]}{m_{j}^{e}[\mathbf{A}[1,1,0], 1]}\right]^{1 / 8} .
\end{gathered}
$$


This index (13) evaluates the effect of change of the proportion of gross value added plus import on employment multipliers. The effect of change of structure of employment can be evaluated as

$$
\begin{gathered}
{\left[\frac{m_{j}^{e}[\mathbf{A}[0,0,0], 1]}{m_{j}^{e}[\mathbf{A}[0,0,0], 0]} \frac{m_{j}^{e}[\mathbf{A}[1,0,0], 1]}{m_{j}^{e}[\mathbf{A}[1,0,0], 0]} \frac{m_{j}^{e}[\mathbf{A}[0,1,0], 1]}{m_{j}^{e}[\mathbf{A}[0,1,0], 0]} \frac{m_{j}^{e}[\mathbf{A}[0,0,1], 1]}{m_{j}^{e}[\mathbf{A}[0,0,1], 0]}\right.} \\
\left.\frac{m_{j}^{e}[\mathbf{A}[1,1,0], 1]}{m_{j}^{e}[\mathbf{A}[1,1,0], 0]} \frac{m_{j}^{e}[\mathbf{A}[1,0,1], 1]}{m_{j}^{e}[\mathbf{A}[1,0,1], 0]} \frac{m_{j}^{e}[\mathbf{A}[0,1,1], 1]}{m_{j}^{e}[\mathbf{A}[0,1,1], 0]} \frac{m_{j}^{e}[\mathbf{A}[1,1,1], 1]}{m_{j}^{e}[\mathbf{A}[1,1,1], 0]}\right]^{1 / 8} .
\end{gathered}
$$

This index (14) evaluates the effect of the change (and absolute level) of employment within individual industries.

Indices presented in equations 11 to 14 are not additive in the sense of total index ( 7 and 8 on index $\left.m_{j}^{e}[1,1] / m_{j}^{e}[0,0]\right)$. Due to that fact it involves more combination of changes, which are not directly interpretable (for eq. $m_{j}^{e}[\mathbf{A}[1,1,0], 0] / m_{j}^{e}[\mathbf{A}[0,0,0], 0]$ ). We aggregate other effects into the simultaneous effect.

\section{Results}

Firstly, we estimate the employment multipliers for the years 2005, 2010 and 2015. We calculate indices (2010/2005, 2015/2010 and 2015/2005) and we aggregate them by weighted mean into basic categories of the Classification of Products (CZ-CPA).

Figure 1 shows that the employment multipliers decrease over time. Some of the industries decrease of $46 \%$ of multiplication of the year 2005. The average is $70 \%$ and the maximum reach $86 \%$. Thus, we can state that the reaction of employment on use of domestic production decrease over time. However, currently, we are not able to say what causes this decrease. That is why we calculate indices (equations $11-14$ ) and the residuum into the total effect simultaneous effect. The simultaneous effect represents directly noninterpretable combination of changes which are not involved in equations $11-14$. This effect represents the effect of simultaneous changes which are not represented by other indices. For example, it represents the simultaneous change of price and employment at the same time with all other factors fixed.

Table 1 states that the strongest effects go to gross value added import and employment effect in 2005-2010. In average, the total decrease of multiplication of employment reach -15\% (Figure 1.). The effect of the size of intermediate use on total output is captured by the gross value added plus import effects and it is the strongest part of decrease the multiplication of employment in this period $(-16.86 \%)$. There is a positive effect of the change of structure and an absolute number of hours worked between the years 2005 and 2010 (4.05\%).

In the period between the years 2010 and 2015 the simultaneous effect affects the total change (-18\% - Figure 1) negatively by $-2.83 \%$. Moreover, the main effect is caused by the change of the proportion of gross value added and export with the intermediate consumption. The average multiplication of employment decreases by $-18 \%$ (Figure 1) on average during this period. The strongest effect brought the change of proportion of intermediate use on total output $(-16.86 \%)$ and the structure affect the multiplication positively $(0.77 \%)$.

The problem of the change of effect of employment on the employment multipliers is easily interpretable. We think it is in the same sense as the economic crisis in the year 2009. Thus, we believe that the manpower was cheaper during the crisis and it allowed firms to hire more workers (total employment - hours worked). This corresponds to the positive effect of change which says that the effect of the change of production function affects the total change of multiplication by $0.75 \%$ for the first period and by $0.77 \%$ for the second period. We can state the firms changed their production function (less price, gross value added plus import, employment and simultaneous effect) in the way that affects employment positively but very 
weakly. This result is in line with other studies published in recent years (for eq. Fischer, et. al. 2018).

Figure 1: Employment multipliers for changes between periods 2010/2005, 2015/2010, $2015 / 2005$

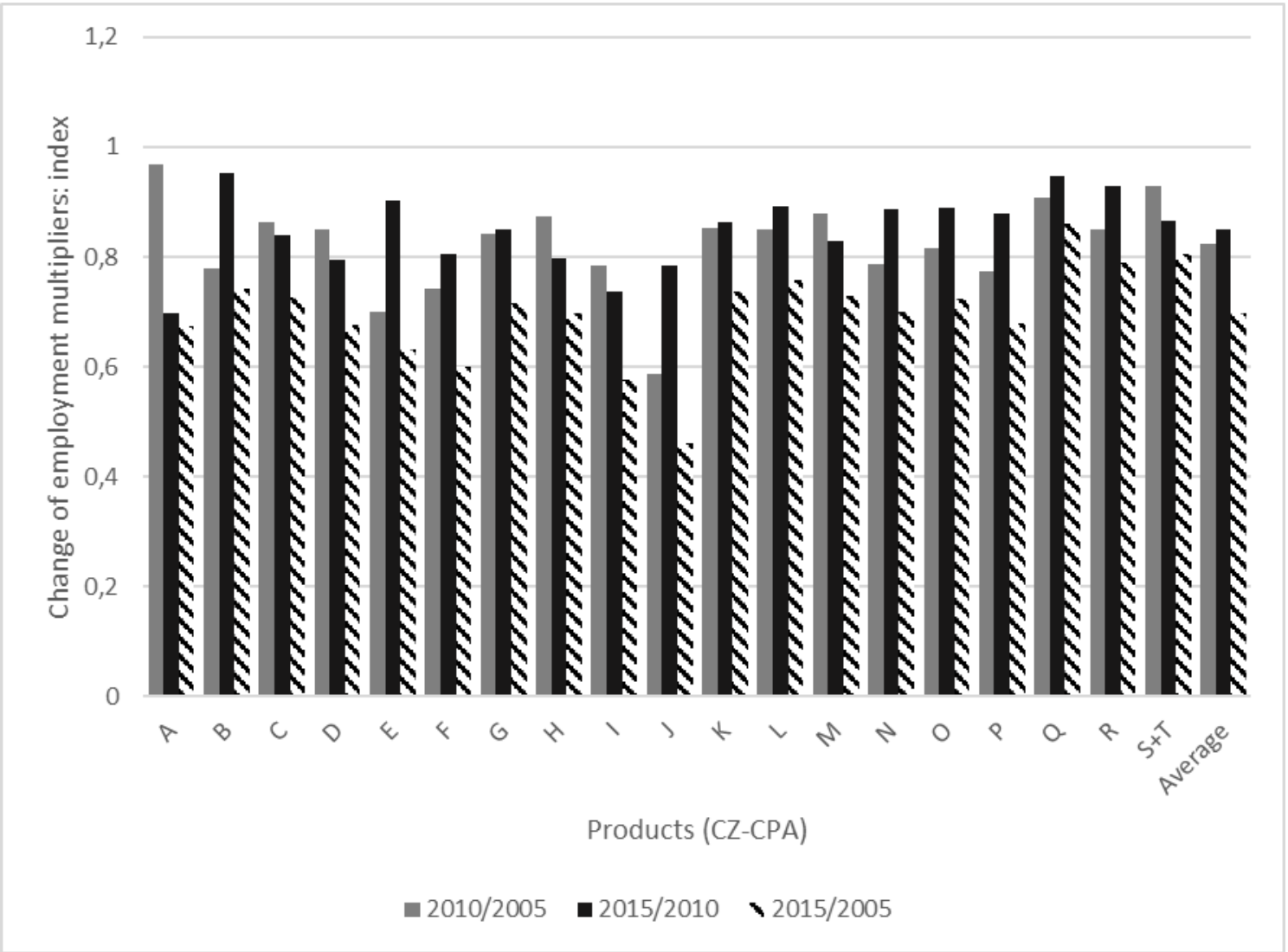

Source: the authors.

There are several economic reasons why the structure of employment affects it more significantly than the change of technical functions (structure of matrix A). One point of view is the effect of aging and the structure of labor force (Langhamrová, et. al., 2018; Šimková et al, 2016). Which can cause a more significant effect than the structural changes in production functions (effect of Structure of A).

This not dramatical results on the level of the total economy can be different on the regional level. There are several studies in recent time which partial results can imply that the effect of structural change can be more dramatical (Květon and Šafr, 2019). On the other hand, these results are calculated on estimated figures (Sixta and Fischer, 2017), which can contain several errors on this very detailed level of analysis.

The reason why the GVA plus Import have the biggest effect on the change of multiplication of employment can be easily interpreted by the change of the proportion between domestic intermediate use and the GVA plus Import. Especially the level of import increases significantly in these years (Rojíček et al., 2012) due to the accession into the European Union. 
Table 1: Index analysis of factors of change of multiplicators of employment (in \%)

\begin{tabular}{|c|c|c|c|c|c|c|c|c|c|c|}
\hline \multirow[b]{2}{*}{ NACE } & \multicolumn{2}{|c|}{ PRICES } & \multicolumn{2}{|c|}{ GVA+import } & \multicolumn{2}{|c|}{ Structure of A } & \multicolumn{2}{|c|}{ Employment } & \multicolumn{2}{|c|}{ Simlutaneous ef. } \\
\hline & $\begin{array}{l}2005- \\
2010\end{array}$ & $\begin{array}{l}2010- \\
2015\end{array}$ & $\begin{array}{c}2005- \\
2010\end{array}$ & $\begin{array}{l}2010- \\
2015\end{array}$ & $\begin{array}{l}2005- \\
2010\end{array}$ & $\begin{array}{l}2010- \\
2015\end{array}$ & $\begin{array}{c}2005- \\
2010\end{array}$ & $\begin{array}{c}2010- \\
2015\end{array}$ & $\begin{array}{l}2005- \\
2010\end{array}$ & $\begin{array}{l}2010- \\
2015\end{array}$ \\
\hline $\mathrm{A}$ & -0.17 & 0.46 & -3.65 & -31.7 & 0.34 & 1.81 & -8.82 & 0.07 & -20.81 & 38.43 \\
\hline B & -0.84 & -0.15 & -19.01 & -0.43 & 2.14 & 0.54 & -7.98 & -4.29 & 26.21 & -18.49 \\
\hline $\mathrm{C}$ & -0.07 & -0.26 & -16.22 & -21.12 & 1.46 & 2.14 & -2.36 & 4.7 & 1.35 & 2.6 \\
\hline $\mathrm{D}$ & -4.44 & -0.99 & -33.58 & -2.14 & 10.07 & 8.07 & -5.52 & 1.02 & 20.24 & -19.57 \\
\hline $\mathrm{E}$ & -0.27 & -0.07 & -21.47 & -6.44 & 0.48 & -2.43 & 7.05 & -0.19 & 6.98 & -23.02 \\
\hline $\mathrm{F}$ & 0.11 & -0.08 & -17.35 & -5.61 & -1.01 & 0.85 & 3.72 & -10.63 & -5.16 & -12.53 \\
\hline $\mathrm{G}$ & -0.2 & 0.22 & -18.45 & -14.69 & 0.52 & 0.49 & 5.47 & -1.51 & -1.46 & -0.64 \\
\hline $\mathrm{H}$ & -0.36 & 0.34 & -18.34 & -13.5 & 1.98 & 0.88 & 4.29 & 1.22 & -7.99 & -1.31 \\
\hline I & -0.4 & 0.25 & -12.37 & -13.4 & -0.08 & -0.44 & 6.22 & -5.71 & -20.42 & -3.89 \\
\hline $\mathrm{J}$ & 0.52 & 1.95 & -24.54 & -14.88 & -3.47 & 1.32 & 8.82 & -2.64 & -1.53 & -31.37 \\
\hline $\mathrm{K}$ & -0.54 & 1.25 & -32.41 & -13.02 & 3.32 & -1.9 & 9.51 & 1.15 & 13.64 & -2.42 \\
\hline $\mathrm{L}$ & -0.75 & 0.46 & -15.71 & -10.85 & -3.18 & 0.85 & 10.36 & -6.57 & -0.23 & 0.61 \\
\hline $\mathrm{M}$ & -0.11 & 0.29 & -18.93 & -12.09 & -0.89 & -0.12 & 8.32 & -1.63 & -4.62 & 1.43 \\
\hline $\mathrm{N}$ & -0.23 & 0.17 & -20.18 & -17.33 & 2.52 & 1.72 & 7.98 & -0.37 & 0.71 & -6.16 \\
\hline $\mathrm{O}$ & -0.17 & 0.33 & -17.09 & -5.69 & 1.03 & 0.13 & 4.49 & -2.53 & 1.73 & -11.68 \\
\hline $\mathrm{P}$ & -0.26 & 0.04 & -19.75 & -12.33 & 0.33 & -0.2 & -2.28 & 1.56 & 12 & -13.09 \\
\hline Q & -0.27 & 0.15 & -24.8 & -14.62 & 0.65 & -0.48 & 7.51 & 4.26 & 16.56 & 2.47 \\
\hline $\mathrm{R}$ & -0.49 & 0.68 & -15.58 & -10.55 & -1.35 & -0.63 & 10.08 & 3.31 & 1.79 & -8.05 \\
\hline $\mathrm{S}+\mathrm{T}$ & -0.17 & 0.28 & -11.77 & -11.18 & -0.76 & 0.09 & 13.07 & 1.18 & -12.31 & 2.86 \\
\hline mean & -0.36 & 0.25 & -16.3 & -16.86 & 0.75 & 0.77 & 4.05 & -0.16 & -2.83 & -1.87 \\
\hline
\end{tabular}

Source: the authors.

\section{Conclusion}

Input-Output the analysis represents one of the tools for the evaluation of the structural changes in the economy. In this paper, we combined the Input-Output analysis with the index analysis. This allowed us to investigate the effects of structural changes of the intermediate use on employment in the Czech economy in the period between the years 2005 and 2015.

The results showed that the structural changes in the Czech economy had no significant impact on the changes in the employment's multiplication. Thus, it had not the influence on the relationship between the final use of domestic use and employment. Significant influence was caused by the change of the ratio of gross value added with import against intermediate consumption. Other important influences were changes in employment. The changes during the years 2005 and 2010 were caused by the decrease in labor costs (relatively) that led to an increase in employment. This relates to the opposite effect in the period between the years 2010 and 2015. The price changes in the period of the pre-economic crises period (2005-2010) and the economic crises period negatively influenced the changes in the multipliers. On the other hand, the price changes positively influenced the multipliers (their increase) in the post-crisis period. This corresponded with the employment effect.

\section{Acknowledgements}

The paper was institutionally supported by the long-term research scheme of the Faculty of Informatics and Statistics of the University of Economics in Prague.

\section{References}

[1] Carter, A. P. 1970. Structural change in the American economy. Harvard : Harvard University Press, 1970. ISBN 9780674493629. 
[2] Das, P. 2013. Sources of growth and structural change in input-output system in India: Estimating temporal Leontief inverse. In The Journal of Income and Wealth, 2013, vol. 35, iss. 1, pp. 145-158.

[3] Dewhurst, J. 1993. Decomposition of changes in input-output tables. In Economic Systems Research, 1993, vol. 5, iss. 1, pp. 41-53.

[4] Fischer, J. et. al. 2018. Regulace dopadů technologických změn na poptávku po pracovní síle. Research report. Prague : University of Economics in Prague, 2018. No ISBN.

[5] Guo, J., Planting, M. A. 2000. Using input-output analysis to measure U.S. economic structural change over a 24 year period. In 13th International Conference on Input-Output Techniques. Macerata, Italy. 2000. 35 pp.

[6] Květon, V., Šafr, K. 2019. Regional embeddedness, relatedness and inter-regional linkages among less developed regions in Central Europe. In European Planning Studies, 2019, vol. 27 , iss. 5 , pp. $862-884$.

[7] Langhamrová, J. et al., 2018. Macroeconomic impacts of the expansion of social services for ageing population of the Czech Republic. In Politická ekonomie, 2018, vol. 66, iss. 2 , pp. 240-259.

[8] Lasi, H. et al. 2014. Industry 4.0. In Business \& Information Systems Engineering, 2014, vol. 4 , iss. 6 , pp. 239-242.

[9] Leontief, W. 1941. The structure of American economy, 1919 - 1929: An empirical application of equilibrium analysis. Harvard : Harvard University Press, 1941. No ISBN.

[10]Leontief, W. 1951. The structure of American economy, 1919 - 1939: An empirical application of equilibrium analysis. Harvard : Harvard University Press, 1951. No ISBN.

[11]Miller, R. E., Blair, P. D. 2009. Input-output analysis: Foundations and extensions. Cambridge : Cambridge University Press, 2009. ISBN 978-0-521-51713-3.

[12]Rojíček, M. 2012. Ownership principle in the foreign trade statistics: Czech approach. In Statistika: Statistics \& Economy Journal, 2012, vol. 49. iss.1, pp. 5-22.

[13] Šimková, M. et al. 2016. Pension liabilities to ageing population of the Czech Republic. In Politická ekonomie, 2016, vol. 64, iss. 5, pp. 591-607.

[14] Sixta, J., Fischer, J. 2017. Estimates of regional flows of manufacturing products in the Czech Republic. In 35th International Conference Mathematical Methods in Economics. Hradec Kralové, Czech Republic, 2017, pp. 667-672.

[15] Sonis, M. et al. 1996. Sources of structural change in input-output systems: A field of influence approach. In Economic Systems Research, 1996, vol. 8, iss. 1, pp. 15-32.

\section{Appendix}

Classification of Economic Activities (CZ-NACE)

\begin{tabular}{ll}
\hline A & PRODUCTS OF AGRICULTURE, FORESTRY AND FISHING \\
B & MINING AND QUARRYING \\
C & MANUFACTURED PRODUCTS \\
D & ELECTRICITY, GAS, STEAM AND AIR CONDITIONING \\
E & WATER SUPPLY; SEWERAGE, WASTE MANAGEMENT AND REMEDIATION SERVICES \\
F & CONSTRUCTIONS AND CONSTRUCTION WORKS \\
G & WHOLESALE AND RETAIL TRADE SERVICES; REPAIR SERVICES OF MOTOR VEHICLES \\
& AND MOTORCYCLES \\
H & TRANSPORTATION AND STORAGE SERVICES \\
I & ACCOMMODATION AND FOOD SERVICES
\end{tabular}


J INFORMATION AND COMMUNICATION SERVICES

K FINANCIAL AND INSURANCE SERVICES

L REAL ESTATE SERVICES

M PROFESSIONAL, SCIENTIFIC AND TECHNICAL SERVICES

N ADMINISTRATIVE AND SUPPORT SERVICES

O PUBLIC ADMINISTRATION AND DEFENCE SERVICES; COMPULSORY SOCIAL SECURITY SERVICES

P EDUCATION SERVICES

Q HUMAN HEALTH AND SOCIAL WORK SERVICES

R ARTS, ENTERTAINMENT AND RECREATION SERVICES

S OTHER SERVICES

T SERVICES OF HOUSEHOLDS AS EMPLOYERS; UNDIFFERENTIATED GOODS AND SERVICES PRODUCED BY HOUSEHOLDS FOR OWN USE

U SERVICES PROVIDED BY EXTRATERRITORIAL ORGANISATIONS AND BODIES 